\title{
Clerical Dissent, Popular Piety, and Sanctity in Fourteenth-Century Peterborough: The Cult of Laurence of Oxford
}

Laura A. Wertheimer

Cleveland State University, I.wertheimer@csuohio.edu

Follow this and additional works at: https://engagedscholarship.csuohio.edu/clhist_facpub

How does access to this work benefit you? Let us know!

\section{Publisher's Statement}

(C) 2006 by University of Chicago Press. Available on publisher's site at http://www.jstor.org/pss/

10.1086/497053.

\section{Original Citation}

Laura A. Wertheimer, "Clerical Dissent, Popular Piety, and Sanctity in Fourteenth-Century Peterborough: The Cult of Laurence of Oxford," Journal of British Studies 45 no. 1 (2006): 3-25.

\section{Repository Citation}

Wertheimer, Laura A., "Clerical Dissent, Popular Piety, and Sanctity in Fourteenth-Century Peterborough: The Cult of Laurence of Oxford" (2006). History Faculty Publications. 15.

https://engagedscholarship.csuohio.edu/clhist_facpub/15

This Article is brought to you for free and open access by the History Department at EngagedScholarship@CSU. It has been accepted for inclusion in History Faculty Publications by an authorized administrator of EngagedScholarship@CSU. For more information, please contact library.es@csuohio.edu. 


\title{
Clerical Dissent, Popular Piety, and Sanctity in Fourteenth-Century Peterborough: The Cult of Laurence of Oxford
}

\author{
Laura Wertheimer
}

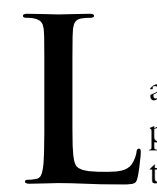

aurence of Oxford went the way of all flesh on the gallows. He died, probably strangled slowly by the weight of his own body, in a Northamptonshire field one spring day in the year 1313. Hundreds of men and women shared his fate each year: it was the penalty normally inflicted on those who, like Laurence, had been convicted of a felony. If his execution was unremarkable, however, the events surrounding it were not. A servant who had been convicted of stealing from his master, the abbot of Peterborough, Laurence featured prominently in a series of lurid tales circulating about his former employer. Before Laurence's execution, rumor in the monastery and surrounding parishes had it that the abbot had engaged in sexual misconduct with Laurence, and stories told after Laurence's execution claimed that the abbot had caused his late servant's death. Even more striking than Laurence's presence in those salacious rumors was what happened after his burial. Undignified though Laurence's passing may have been, individuals within the monastery and surrounding parishes awarded him posthumously the greatest honor they could bestow: they made his grave site the object of a small religious cult.

The appearance of Laurence's cult was no small source of consternation to John Dalderby, bishop of Lincoln, in whose spiritual jurisdiction the region lay. Over the next six months, the bishop was forced to write letter after letter commanding various ecclesiastical subordinates to eliminate what he considered a superstition

Laura Wertheimer is assistant professor of history at Cleveland State University. Research from this article was carried out through the generous support of Cleveland State University, the Huntington Library, and the British Academy. An earlier version of this article was presented at a session of the White Hart Society at the 2004 International Congress on Medieval Studies; the author would like to thank the participants in the session. The author would also like to thank Michael Burger, Elizabeth Lehfeldt, and Don Ramos, as well as the readers at JBS for their comments.

Journal of British Studies 45 (January 2006): 3-25

(C) 2006 by The North American Conference on British Studies.

All rights reserved. 0021-9371/2006/4501-0001\$10.00 
deviating from the path of true faith. ${ }^{1}$ It was Dalderby's right-indeed, his obligation-as bishop to do so, for the fourteenth-century institutional church firmly believed in its unique authority to guide both lay and clerical religiosity. ${ }^{2}$ It viewed all forms of religious expression not under clerical guidance with suspicion, and while the church did not identify all unapproved potential saints' cults as heresy, it easily dismissed them as superstition and error better laid aside in favor of officially approved cults. In the movement explored by this article, however, a local community defied ecclesiastical authorities' power over their religious practices by treating one of their own members as a saint.

Modern study of unsanctioned saints' cults began several decades ago, within a larger scholarly effort to investigate how religious beliefs and practices unstructured by the church might reveal previously unexplored facets of both medieval piety and medieval society itself. ${ }^{3}$ The full range of medieval religious expression has been difficult to uncover because virtually all our sources are clerical in origin. Liturgical, disciplinary, and didactic texts alike flowed from the pens of individuals whose idealized Christian society was, almost by definition, one in which all the faithful held uniform beliefs and followed the uniform practices that proceeded from them. Beginning in the 1960s, historians began searching for the religious experiences of the people who left no written records of their own beliefs; though these scholars took a variety of approaches, among the most influential techniques has been the use of analytical tools developed in the disciplines of anthropology and folkloric studies to read against the grain of official church documents such as inquisitorial records. ${ }^{4}$ Pioneers of this work concluded that the Christian culture of the Middle Ages was far from a united one but rather included a "popular" religion (or popular culture) quite distinct from that of clerical authors. ${ }^{5}$

\footnotetext{
${ }^{1}$ Lincoln, Lincolnshire Archives Office (LAO), Episcopal Register 3, fols. 276v, 279, 280v, 281v, 283,285 , and 289v. The letters spanned late June to early November 1313.

${ }^{2}$ One of the greatest challenges confronting ecclesiastical historians is the meaning of the term "the church," which can imply a monolithic unity of beliefs, practices, and institutions that did not exist in the Middle Ages. This article uses "the church" or "institutional church" to refer collectively to the clerical hierarchy meant to enact the Christian beliefs and practices established through channels such as canon law, papal and conciliar decrees, and university scholarship. See Gary Macy, "Was There a 'The Church' in the Middle Ages?" in Studies in Church History, ed. R. N. Swanson (Oxford, 1996), 32:107-16; and R. N. Swanson, "University and Diversity, Rhetoric and Reality: Modeling "the Church," Journal of Religious History 20, no. 2 (December 1996): 156-74.

${ }^{3}$ The historiographical literature on this topic is extensive. For discussion see in particular John Van Engen, "The Christian Middle Ages as an Historiographical Problem," American Historical Review 91 (June 1986): 519-52; also Natalie Zemon Davis, "From 'Popular Religion' to Religious Cultures," in Reformation Europe: A Guide to Research, ed. Steven Ozment (St. Louis, 1982), 321-41; Miri Rubin, "Religious Culture in Town and Country," in Church and City, 1000-1500: Essays in Honor of Christopher Brooke, ed. David Abulafia, Michael Franklin, and Miri Rubin (Cambridge, 1992), 3-22; Jean-Claude Schmitt, "Religion, Folklore, and Society in the Medieval West," in Debating the Middle Ages: Issues and Readings, ed. Lester K. Little and Barbara H. Rosenwein (Malden, MA, 1998), 367-87.

${ }^{4}$ For example, see Carlo Ginzburg, The Cheese and the Worms: The Cosmos of a Sixteenth-Century Miller, trans. John and Anne Tedeschi (New York, 1982), and The Night Battles: Witchcraft and Agrarian Cults in the Sixteenth and Seventeenth Centuries, trans. John and Anne Tedeschi (Baltimore, 1992); and Emmanuel Le Roy Ladurie, Montaillou, the Promised Land of Error, trans. Barbara Bray (New York, 1979).

${ }^{5}$ It should be noted that the vocabulary of this field, particularly use of the word "popular," is highly contentious: see Leonard Boyle, "Popular Piety in the Middle Ages: What Is Popular?" Florilegium 4 (1982): 184-93; and Schmitt, "Religion and Folklore," 377-78.
} 
Debate within this research initially focused on how Christian this posited popular culture was. Scholars such as John Delumeau and Gabriel Le Bras concluded that medieval popular religion represented a weakly Christianized or even cryptopagan folk culture, while Etienne Delaruelle and Jean-Claude Schmitt have argued that the late medieval lay population was thoroughly Christianized. ${ }^{6}$ Regardless of their conclusions about the depth of Christianity's penetration into medieval society, though, scholars who pioneered these studies concluded in common that the literate, elite, clerical culture that produced the sources on medieval religion existed separate from, and frequently in conflict with, a lay, oral, nonelite culture. Partly in response to this proposed bifurcation of medieval culture, historians such as Eamon Duffy and Miri Rubin have argued that texts showing points of intersection between lay and clerical society reveal the importance of beliefs, rituals, and practices shared by all medieval Christians. ${ }^{7}$ They have therefore challenged the idea that there was a religious culture belonging uniquely to the laity or any subset of it.

Though scholars in the former school have softened the sharp line they at first drew through medieval society, they still argue that recognition of a split between a clerical, elite culture and a lay, nonelite, folkloric culture must hold pride of place in studies of medieval religion. Those in the latter group conclude that continuing research has only further demonstrated the artificiality of that model, arguing instead that laity and clergy were united by many common religious practices and beliefs and that stratification within the clergy often meant that men and women in the religious life had more in common with their lay social peers than with members of other ranks of the clergy. Both schools, however, suggest that the debate would benefit from focused, local studies that examine individual movements within their particular historical contexts. ${ }^{8}$

The case of Laurence of Oxford provides an opportunity for such a study. When John Dalderby denounced the venerations at Laurence's grave site as "superstition," he employed a timeless pejorative that denies a practice either religiosity or historicity. This article restores both to the cult. It places the movement firmly within the scholarship arguing that forms of medieval religious expression could unite rather than divide members of the laity and clergy: unlike what scholars have seen in similar unsuccessful saints' cults, individuals from both groups advocated Laurence's cult even though it ran contrary to the institutional church's model of sanctity. The venerations at Laurence's grave site, however, represent far more than a featureless weight in a scale of evidence pertaining to a broad historiographical debate. Contained within Dalderby's episcopal register is what James Scott has identified as a "hidden transcript": the palimpsest of a story much more complex than the one the bishop wished to tell. ${ }^{9}$ When analyzed with other con-

\footnotetext{
${ }^{6}$ Van Engen, "Christian Middle Ages," 521-22, 528-31.

${ }^{7}$ Eamon Duffy, The Stripping of the Altars: Traditional Religion in England c. 1400-1580 (New Haven, CT, 1992); Miri Rubin, Corpus Christi: The Eucharist in Late Medieval Culture (Cambridge, 1993). For discussion and critique of Duffy see Katherine L. French, "Competing for Space: Medieval Religious Conflict in the Monastic-Parochial Church at Dunster," Journal of Medieval and Early Modern Studies 27, no. 2 (1997): 215-44.

${ }^{8}$ Van Engen, "The Future of Medieval Church History," Church History: Studies in Christianity and Culture 17 (September 2002): 517; Schmitt, "Religion, Folklore, and Society," 382.

${ }^{9}$ Scott, Domination and the Arts of Resistance: Hidden Transcripts (New Haven, CT, 1990), 4-16.
} 
temporary sources, this transcript reveals that the advocates of Laurence's cult had more in common than their belief in the man's sanctity. Joined as well by an inability to effect change in the social and political structures in which they lived, they collectively appropriated long-standing ideas about sainthood to further their common goal of challenging the leadership of the most powerful individual in the region: Godfrey of Crowland, the abbot of Peterborough.

\section{ABBEY, ABBOT, AND SERVANT}

Godfrey's power stemmed from his leadership of a monastery that stood at the nexus of overlapping spiritual and secular spheres. ${ }^{10}$ Peterborough, now a cathedral in its own right, was in the fourteenth century a Benedictine house within the vast diocese of Lincoln. ${ }^{11}$ Its primary purpose was to provide its sixty-odd monks with a place where they could withdraw from the world to seek their own salvation and pray for the souls of others under the guidance of their abbot, but it served several other religious functions as well. ${ }^{12}$ Pilgrims came to venerate the relics of St. Thomas Becket that rested in a chapel just within the outer gate of the abbey grounds. ${ }^{13}$ In keeping with the Benedictine obligation to offer alms and aid to the needy, Peterborough maintained a hospital associated with St. Thomas's chapel; here the house provided for the physical and spiritual needs of the infirm. Benedictine monks did not normally minister directly to the laity, but the abbey was responsible for nominating priests to serve in churches throughout the region. These included churches on lands under the house's secular control and churches it had "appropriated," an arrangement under which the abbey received the church's revenues and paid a vicar to perform any necessary pastoral duties. ${ }^{14}$

By the fourteenth century, landholding monasteries' adherence to the ideal of monastic isolation had long since crumbled under the pressures imposed by their properties, and a Benedictine abbot not only had to govern his monks but also had to supervise management of the house's estates and carry out any political or administrative duties that those lands imposed. Peterborough Abbey was no exception. The house possessed estates, manors, and villages in Northamptonshire, Lincolnshire, and beyond, from which it drew income. ${ }^{15}$ It also enjoyed a relatively

\footnotetext{
${ }^{10}$ For the religious life see Janet Burton, Monastic and Religious Orders in Britain, 1000-1300 (Cambridge, 1994); David Knowles, The Monastic Order in England, 2nd ed. (Cambridge, 1963), and The Religious Orders in England, vol. 2, The End of the Middle Ages (Cambridge, 1961); and Michelle Still, The Abbot and the Rule: Religious Life at St. Albans, 1290-1349 (Aldershot, UK, 2002).

${ }^{11}$ A brief history of the abbey may be found in R. M. Serjeantson and W. Ryland D. Adkins, eds., The Victoria County History of the County of Northampton (London, 1906), 2:83-95 (hereafter cited as $\mathrm{VCH}$ Northants.).

${ }^{12}$ The house had eighty monks in the early thirteenth century, but only sixty-four at the onset of the plague in 1348. Edmund King, Peterborough Abbey, 1086-1310: A Study in the Land Market (Cambridge, 1973), 93; VCH Northants., 2:26.

${ }^{13}$ Edmund King, "Benedict of Peterborough and the Cult of Thomas of Becket," Northamptonshire Past and Present 9, no. 3 (1996-97): 213-20.

${ }^{14}$ N. J. G. Pounds, A History of the English Parish: The Culture of Religion from Augustine to Victoria (Cambridge, 2000), 50-54. See also R. A. R. Hartridge, A History of Vicarages in the Middle Ages (New York, 1968); and Ulrich Rasche, "The Early Phase of Appropriation of Parish Churches in Medieval England," Journal of Medieval History 26, no. 3 (2000): 213-37.

${ }^{15}$ King, Peterborough Abbey, chaps. 1 and 8; Kathleen Biddick, The Other Economy: Pastoral Husbandry on a Medieval Estate (Berkeley, 1989).
} 
unusual and quite advantageous relationship with the legal unit known as the Soke (or Liberty) of Peterborough, which encompassed the town of Peterborough and extended west to the suburbs of the town of Stamford. Acting on the monastery's behalf, the abbot held extensive jurisdiction over the Soke. ${ }^{16}$ A summary of his rights written in 1329 shows that he maintained the gaol where accused felons were held, carried out the execution of those convicted, and collected most of the profits from justice in the Soke, including the revenues from fines and the confiscated chattels of convicted felons and fugitives. ${ }^{17}$ The abbot's presence throughout the region was therefore nearly inescapable, and his actions could profoundly affect those who lived within it.

Godfrey took his name from the place of his birth, a village in Lincolnshire about ten miles distant from Peterborough. Little is currently known about Godfrey's family or his life prior to his abbacy. His parents were John of Crowland and Alexandra, both of whom were buried in the cemetery of Crowland's parish church. ${ }^{18} \mathrm{He}$ had siblings, but his entrance into the religious life would indicate that he was not the eldest son. ${ }^{19}$ One of his sisters, who bore the unusual name "Silverona," married at Godfrey's arrangement a freed villein of the abbey called Benedict of Eye and gave birth to at least one son, Richard, who became one of the abbot's most valued lay administrators. ${ }^{20}$

It is likely but not certain that Godfrey was professed as a monk at Peterborough; he was definitely at the house no later than $1292 .{ }^{21}$ Prior to becoming abbot in 1299 , Godfrey was an officer responsible for distributing provisions to the monks. ${ }^{22}$

${ }^{16}$ VCH Northants., 2:421-27; W. T. Mellows, ed., Peterborough Local Administration: Parochial Government before the Reformation, Churchwardens' Accounts, 1467-1573, with Supplementary Documents, 1107-1488, Publications of the Northamptonshire Record Society 9 (Kettering, Northants., 1939), xi-xvii.

${ }^{17}$ Placito de Quo Warranto Temporibus Edw. I. II. \& III (London, 1818), 551-52.

${ }^{18}$ LAO, Episcopal Register 3, fol. 415v.

${ }^{19}$ A donation charter he issued in 1308 referred to his brothers and sisters, both in the plural. Walteri de Whitlesey, Historia Coenobii Burgensis, in Historiae Anglicanae scriptores varii, ed. Joseph Sparke, 2 vols. (London, 1723), 2:158.

${ }^{20}$ Edmund King has demonstrated that the land market around Peterborough in the late thirteenth and early fourteenth centuries produced a prosperous "kulak class" among the abbey's serfs; Benedict presumably belonged to this group. King, Peterborough Abbey, 110. The source, Henry Pytchley, did not name the sister, but a notation in Dalderby's register granted an indulgence to those praying for the souls of Benedict of Eye and his wife Silverona. This article assumes that Silverona was Godfrey's sister rather than a later wife. Henry of Pytchley's Book of Fees, ed. W. T. Mellows, Northamptonshire Record Society 2 (Kettering, UK, 1927), 142; LAO, Episcopal Register 3, fol. 415v. For Richard's role in the abbey's administration see King, Peterborough Abbey, 137-38.

${ }^{21}$ Walter Whittlesey's description of Godfrey as "Godefridus venerabilis monachus Burgi et professus, natus et vocatus de Croyland" (retaining Sparke's punctuation) can be translated to indicate that Godfrey was professed either at the monastery of Crowland or at Peterborough. Sandra Raban, in her introduction to Godfrey's register, uses the former reading, but Whittlesey's description of several other Peterborough abbots as monachus Burgi et professus suggests that the latter translation may be preferable. Sparke, Historia Anglicanae, 2:132, 145, 153; Sandra Raban, ed., The White Book of Peterborough (Northampton, UK, 2001), xxvii. Godfrey was named as a monk of Peterborough in a charter he witnessed in 1292. Thomas Stapleton, ed., Chronicon Petroburgense, Publications of the Camden Society 47 (London, 1849), 150.

${ }^{22}$ Whittlesey stated that Godfrey had been elected abbot from the office of pittancer and had previously held the office of cellarer. Sparke, Historiae Anglicanae, 2:153, 170-71; for discussion of the offices see Knowles, Monastic Order, 429-30. The seventeenth-century antiquarian Simon Gunton stated that Godfrey had been elected from the office of cellarer; Gunton was followed by the Victoria 
He was elected abbot in October of 1299 per viam compromissi (selection by a committee chosen by the house rather than by general election) and made his formal entrance into the monastery on 29 December. ${ }^{23}$ Godfrey could not have been elected without support from members of the monastery, but Peterborough, which owed its feudal obligations directly to the king, was also obliged to choose an abbot acceptable to the monarch. ${ }^{24}$ Godfrey seems to have had Edward I's particular favor: following the abbot's election the king sent him a valuable cup as a gift, forgave some of the monastery's debts, and confirmed the abbot's charters and liberties. ${ }^{25}$

Dalderby's register of diocesan business yields little other information about the next thirteen years at the house. The chronicle of Walter Whittlesey, Godfrey's contemporary, suggests that the abbot spent lavishly on ornaments for the monastery and himself and to entertain important guests at the abbey. ${ }^{26}$ Godfrey enjoyed hunting; he was pardoned twice for poaching in the royal forests and apparently incurred the enmity of the abbot of Thorney for hunting on his lands. ${ }^{27}$ Godfrey was also a vigorous and active administrator with a passion for building. The continuator of the Peterborough chronicle attributed to John of Caux described him as a "magnificent" man who was remarkably diligent in managing the abbey's temporalities, and Whittlesey enumerated at length the abbot's building projects and other contributions to the monastery. ${ }^{28}$ Subsequent histories of the abbey, following these sources, also memorialized Godfrey's dedication to building and improving the house's possessions. ${ }^{29}$ But as we shall see, Godfrey also faced controversies and criticisms.

According to a letter in Dalderby's register, early in the year 1313 the bishop learned that the abbot of Peterborough was "in no small way defamed" by insinuations of certain serious offenses. ${ }^{30}$ At that time, rumor said that Abbot Godfrey had carnal knowledge of four women of the town of Peterborough: three single women, Margaret the Stabler, Margaret of Ketton, and Alice the daughter of Alan the Fletcher; as well as Agnes Dochild, who was the wife of Laurence of Oxford.

County History. Simon Gunton, History of the Church of Peterburgh (London, 1686), 39; VCH Northants., 2:89.

${ }^{23}$ Rosalind M. T. Hill, ed., The Rolls and Register of Bishop Oliver Sutton, 1280-1299, 7 vols., Lincoln Record Society (Lincoln, UK, 1948-75), 6:165.

${ }^{24}$ John Russell, "Ordeal on Horseback: The Peterborough Abbatial Elections of 1321 and 1338," Northamptonshire Past and Present 9, no. 3 (1996-97): 221-26.

${ }^{25}$ Sparke, Historiae Anglicanae, 2:153-54.

${ }^{26}$ Ibid., 2:153-73. Extravagant spending on important visitors was a common practice-and a common source of complaints-in large monastic houses. Edwin N. Gorsuch, "Mismanagement and Ecclesiastical Visitation of English Monasteries in the Early-Fourteenth Century," Traditio 28 (1972): $473-82$.

${ }^{27}$ Raban, White Book, xxviii; Sparke, Historiae Anglicanae, 2:171-73; Chancery Miscellanea, pt. V, List and Index Society 49 (London, 1970), 275; Calendar of the Patent Rolls (CPR), Edward I, AD 1301-7, 357, and Edward II, AD 1313-17, 480 .

${ }^{28}$ Sparke, Historia Anglicanae, 1:125.

${ }^{29}$ Gunton, History of the Church of Peterburgh, 40; VCH Northants., 2:89.

${ }^{30}$ LAO, Episcopal Register 3, fol. 270v, issued 23 February. According to the bishop's letter, Godfrey was defamed by "clamorous insinuation and rumor" (insinuacione clamosa et fama; this article retains the original spellings in all instances). Some scholars argue that "gossip" rather than "rumor" is appropriately applied to stories intended to defame a particular individual; "rumor," however, is the more common translation of fama. Scott, Domination, 142-44. 
In addition, it was alleged that Godfrey had permitted thieves to carry off church goods deposited at the manor of Eye (a nearby manor where the abbot frequently resided). Rumor claimed that prior to Godfrey's actual election as abbot, he had instructed the custodians of Peterborough's gaol to treat those incarcerated within it too harshly, causing the death of one of them. ${ }^{31}$ Finally, rumor said that the abbot had committed the sin of sodomy with his chamberlain Laurence of Oxford, to the danger of his soul, disgrace of the religious order, and the grave scandal of a great many people. ${ }^{32}$

In response to these charges, Godfrey's representative presented himself before the bishop on 23 February 1313 to hear and deny the allegations on the abbot's behalf in a ceremony known as a compurgation, in which a defamed person heard allegations against him read publicly and solemnly and then refuted them with an equally public and solemn oath. ${ }^{33}$ In accordance with this procedure, the agent took a formal oath, supported by those of other "trustworthy men," attesting to Godfrey's innocence. Dalderby then declared the abbot blameless on all accounts and pronounced his good reputation restored.

Meanwhile, Godfrey's servant Laurence faced problems far more serious than a straying wife or being asked to perform services not normally expected of a chamberlain. While the court of public opinion may have believed that Godfrey had let thieves steal abbey goods, a local court in the Soke of Peterborough indicted Laurence for carrying them off, and two months after witnesses swore to the bishop that Godfrey was innocent of miscellaneous sins, a jury declared to two royal justices that Laurence was guilty of a felony crime. ${ }^{34}$

Laurence's trial and execution, the key to understanding the cult honoring him, appear only in a previously unexamined entry within a set of royal records known as gaol delivery rolls. ${ }^{35}$ This record shows that on 23 April, the royal justices Henry Spigurnel and Hugh Wake took "delivery" of Peterborough's gaol; that is, they conducted the trials of individuals under felony indictment who were either incarcerated in the gaol or released on bail from it as they awaited trial. The summary of Laurence's trial shows that he was charged with robbery committed against the abbot of Peterborough at the manor of Eye; the stolen goods appear to have been tableware, perhaps altar vessels, and some cash, all worth a total of twelve pounds. ${ }^{36}$ Fourteen other men stood trial as accomplices or recipients of the goods. Three of them claimed that they were clerics, exempting them from secular punishment, and the vicar of the parish church of Peterborough duly presented documentation

\footnotetext{
31 "ante tempus electionis de ipso facte in abbatem." LAO, Episcopal Register 3, fol. 270v.

${ }^{32}$ Laurence was identified as the abbot's camerarius. In monastic documents this term normally indicates the officer responsible for the monks' wardrobe, but it could also refer to a chamber-servant or valet, which was probably the case here.

${ }^{33}$ R. H. Helmholz, "Crime, Compurgation, and the Courts of the Medieval Church," in Canon Law and the Law of England (London, 1987), 119-44.

${ }^{34}$ London, Public Record Office (PRO), JUST 3/51/1 m.9.

${ }^{35}$ For discussion of English criminal trial proceedings see J. G. Bellamy, The Criminal Trial in Later Medieval England (Toronto, 1998), 1-9; and Frederick Pollock and Frederic William Maitland, The History of English Law before the Time of Edward I, 2nd ed. (Cambridge, 1968), 527-32. For the gaol delivery rolls, see Barbara Hanawalt, ed., Crime in East Anglia in the Fourteenth Century: Norfolk Gaol Delivery Rolls, 1307-1316 (Norwich, 1976), 5-8.

${ }^{36}$ PRO, JUST $3 / 51 / 1 \mathrm{~m} .9$, "de diversis bonis et catallis scilicet de bacinis cip[his] pycheriis distis calsariis argenteis florenis et aliis iotalibus aureis et argenteis ad valentiam ducentarum Li[brarum]."
} 
to that effect on behalf of the bishop of Lincoln. ${ }^{37}$ Several of the other alleged accomplices were apparently tenants at the manor of Eye: Robert, son of Henry le Newbonde was a reaper, Henry of Warmington was a park-keeper, Richard of Easton was a doorkeeper, and a man whose name is lost to damage was a gardener. ${ }^{38}$

A jury of local men found Laurence alone guilty, acquitting all the others. It is now impossible to determine Laurence's guilt or innocence, but one hint still survives. Gaol delivery rolls routinely included the value of a convicted felon's chattels because these would be confiscated either by the crown or by whatever other authority possessed that privilege-in this case, the abbot of Peterborough himself. Laurence's chattels were listed as twenty shillings of his own and goods from the robbery worth ten pounds. We can, unfortunately, now only speculate on how the stolen goods arrived in Laurence's possession, but there is no doubt about the outcome of the trial. An abbreviated letter "S" in the margin of the court record signifies suspensus: he was hanged.

Laurence was subsequently interred in Peterborough's hospital connected to Becket's chapel. The reasons for his burial there are unknown, but there is evidence that a monastery's servants might be buried within the institution's precincts, and dying a felon's death did not preclude finding repose in sacred ground..$^{39}$ Laurence's execution brought the abbot no peace; indeed, his death was laid at Godfrey's feet. Over the next few weeks a new series of rumors about the abbot's misconduct was bruited about, until the situation became serious enough for the bishop to visit Peterborough personally to address it.

On 14 May, Dalderby attended an assembly of the monastery's full chapter to hear another set of charges formally leveled against the abbot. ${ }^{40}$ This time, in addition to claiming that Godfrey had somehow caused Laurence's death, the charges included the accusation that the abbot had revealed confessions made to him by his brother monks and that he had given Laurence of Oxford's wife three dresses on the "execrable" occasion of knowing her carnally. Godfrey again purged himself of the allegations, this time with an oath taken personally and supported by oaths of some of the abbey's monks. The bishop issued formal letters to this effect on 26 May, proclaiming Godfrey's innocence and once again declaring his reputation restored.

Dalderby made no mention at the time of any improper practices at Laurence's grave site; perhaps they had not yet begun. The cult was clearly established, however, by late June, and as other scholars have noted, its emergence so hard on the heels of the previous troubles at Peterborough can be no coincidence. ${ }^{41}$ How could the grave of an executed felon suddenly become the location of a shortlived but stubborn saint's cult? To understand this, we must look at evidence of broader discontent with the man who was clearly pivotal to the events leading up

\footnotetext{
${ }^{37}$ In late medieval England, the practice was to try accused clerics in a secular court and then hand them over to an ecclesiastical court for punishment if they were convicted. See C. R. Cheney, "The Punishment of Felonous Clerks," in The English Church and Its Laws, 12th-14th Centuries, no. 11 (London, 1982).

${ }^{38}$ messor, parcarius, custos, and gardinarius.

${ }^{39}$ Christopher Daniell, Death and Burial in Medieval England, 1066-1500 (London, 1997), 90, 120,149 .

${ }^{40}$ LAO, Episcopal Register 3, fol. 274v.

${ }^{41}$ Raban, White Book, xxviii-xix; VCH Northants., 2:89.
} 
to the cult's appearance: Godfrey of Crowland, Laurence's alleged partner in sin, the victim of his crime, and the head of Peterborough Abbey.

Scattered evidence suggests longer-term dissatisfaction with Godfrey's management. Only eight months after Godfrey's assumption of the abbacy, Dalderby wrote to the abbot and the house concerning "rebellions and dissensions" that were reported in the monastery. ${ }^{42}$ The letter exhorted the brothers to obedience and urged the abbot to govern with moderation. In 1309, the abbot granted his nephew Richard possession of recently acquired land in Walton contrary, according to a later monk of Peterborough named Henry Pytchley, to the abbey's wish. Pytchley wrote at the very end of the fourteenth century; the abbot's action must have been bitterly resented indeed if it was worth mentioning more than eighty years after the fact. ${ }^{43}$

Discontent with the abbot seemingly came to a head in the months preceding the cult, as is revealed in the certifications of the abbot's two compurgations on 23 February 1313 (two months before Laurence's death) and 14 May (about three weeks after the execution). The rumors evincing dissatisfaction with Godfrey must have been widespread, since compurgations were called only to deal with specific and widely known allegations; whether or not they were true or even believable is another, undeterminable matter. ${ }^{44}$ One charge dredged up an action supposedly committed fourteen years earlier, that Godfrey had caused the death of a prisoner in Peterborough's gaol through an order he issued before his election as abbot (that is, before he had the authority to do so). ${ }^{45}$ Perhaps the charge had real meaning to those repeating the tale. It seems highly likely that abbey goods were indeed stolen, and the record of Laurence's trial shows that he was indicted and executed within the abbot's secular jurisdiction; whether Godfrey contributed directly to either event will remain a mystery. The records tell nothing but the names of the three single women with whom Godfrey supposedly committed fornication, but the repetition of the abbot's supposed affair with Laurence's wife and the touch of detail about the gifts he gave her may indicate that there was something behind the rumor; this too is only speculation.

"Sodomy" is the most intriguing of the charges, both because of recent scholarly interest in medieval concepts of sexuality and because the abbot purportedly committed it with Laurence himself. It is also, however, the one I find most suspect. Sodomy was a highly charged word in the fourteenth century, and one that had been constructed in progressively worsening terms over the course of the high and late Middle Ages. ${ }^{46}$ Savage rhetorical attacks on the sexual pollution of sodomy and its association with heresy appeared in ecclesiastical writings in the mid-eleventh century; by the late Middle Ages it fell on a spectrum of grave sins such as

\footnotetext{
${ }^{42}$ The letter survives in both Dalderby's and Godfrey's registers. LAO, Episcopal Register 3, fol. 16, dated 22 August 1300; Raban, White Book, no. 138, dated 21 August.

${ }^{43}$ Raban, White Book, no. 115; Mellows, Book of Fees, 142.

${ }^{44}$ Helmholz, "Crime, Compurgation, and the Courts," 131-33.

${ }^{45}$ LAO, Episcopal Register 3, fol. 270v.

${ }^{46}$ Carolyn Dinshaw, Getting Medieval: Sexualities and Communities, Pre- and Postmodern (Durham, NC, 1999), 55-99; Michael Goodich, The Unmentionable Vice: Homosexuality in the Later Middle Ages (Santa Barbara, CA, 1979).
} 
simony, idolatry, and blasphemy. ${ }^{47}$ A vivid illustration of this developing trend appeared at the very beginning of the fourteenth century, when Philip IV of France employed allegations of sodomy and other misbehaviors to great effect against Pope Boniface VIII in 1303 and the Knights Templar in 1307, continuing until their final destruction in $1314 .^{48}$ The brothers of Peterborough had direct knowledge of the effect such claims could have: they counted among their ranks a former Knight of the Order of the Temple, who was relegated to the monastery in 1311 when the Order in England was largely dissolved. ${ }^{49}$

There is, however, scholarly debate about both the literal and figurative meaning of sodomy, which did not inherently indicate sexual intercourse between men. ${ }^{50}$ In and of itself, it did not produce severe backlash: purported heresy, blasphemy, and idolatry all led to Boniface's arrest and brought the last of the Templars to the stake. In fact, when unbuttressed by similarly dramatic claims, sodomy was a nearly stereotypical allegation directed against members of the clergy, whose putative isolation from potential female partners supposedly made them more vulnerable to the temptation of sodomitical relations with other men. ${ }^{51}$ (This, incidentally, would have been an advantage of naming a layman in Godfrey's service as his partner: it would stave off the logical conclusion that the stories of the abbot's unnatural sexual practices came from monks with firsthand knowledge of them. $)^{52}$ Scholars do not necessarily take seriously claims that either groups or individuals alleged to have committed sodomy actually did so, and it is quite possible that those rumors about Godfrey were merely an easy and topical way to besmirch the abbot's character. ${ }^{53}$

Whether or not they were true, the rumors struck against Godfrey on every level, depicting him as scandalous in his personal morality, indiscreet in fulfilling his spiritual obligations, delinquent in his oversight of the abbey's temporal possessions, and abusive in the execution of his legal duties. Though Godfrey was twice declared innocent of all misconduct imputed to him, he went on pilgrimage immediately after his second purgation. Pilgrimage was often a penitential act in the Middle Ages; Godfrey's departure was perhaps a tacit admission of some sin that required repentance. Intriguingly, the first royal writ permitting Godfrey to leave the realm was dated four days before the chapter meeting where Dalderby presided over Godfrey's second purgation, strongly suggesting that the bishop came to Peterborough not to determine whether the rumors about Godfrey were true, but rather to take part in a piece of theater meant to put those allegations

\footnotetext{
${ }^{47}$ Malcolm Barber, The Trial of the Templars (Cambridge, 1978), 180-82; and Goodich, Unmentionable Vice, 7-10, 19, 28-31.

${ }^{48}$ Barber, Trial of the Templars, 23-24, 108-9, 178-92; Anne Gilmour-Bryson, "Sodomy and the Knights Templar," Journal of the History of Sexuality 7, no. 2 (1996): 151-83.

${ }^{49}$ Barber, Trial of the Templars, 193-204. The Templar was "John de Stoke," a priest. LAO, Episcopal Register 3, fol. 223.

${ }^{50}$ See Mark Jordan, The Invention of Sodomy in Christian Theology (Chicago, 1997).

${ }^{51}$ Dinshaw, Getting Medieval, 69-71.

${ }^{52}$ Ibid., 77.

${ }^{53}$ In considering the collective allegations of the abbot's sexual misconduct, it may be worth noting that King estimates Godfrey's nephew, Richard, was born around 1265. If this estimate is correct and we posit that Godfrey was at least twenty years older, he was born in 1245 or earlier. It would be a spry septuagenarian who could carry on five sexual affairs simultaneously. King, Peterborough Abbey, 138 n. 4.
} 
to rest. ${ }^{54}$ Godfrey's departure on pilgrimage may also have been intended to let the rumors about him die down, but if so, it failed. The abbot's absence from the monastery apparently offered instead the opportunity for his opponents to take a new approach in their campaign against him-treating as a saint the man whose death Godfrey allegedly caused.

\section{RELIGIOUS CULTURES, PIETY, AND SANCTITY IN THE MIDDLE AGES}

Whether a thief, a sodomite, a hapless cuckold, or all three, Laurence seems an unlikely candidate for sainthood. Yet unidentified miracles supposedly occurred upon his inhumation, and worshippers flocked to his grave site. This horrified John Dalderby, who refused to recognize the potential holiness of a man hanged for a thief. Sanctity, he would have thought, was for the institutional church to decide, but in truth medieval sainthood was a far more complex concept than he was willing to concede..$^{55}$ Vexing though it may have been to the bishop, that complexity has made sainthood an invaluable tool for historians investigating not only the rich diversity encompassed in medieval religiosity but also what that diversity can reveal about medieval culture and society as a whole. ${ }^{56}$

Among other things, the study of saints can illuminate the debate on whether literate, elite, clerical religious culture was distinct from or interwoven with oral, nonelite, popular or folk religious culture. Both successful and unsuccessful saints represent interactions between lay and clerical religiosity: potential saints who achieved canonization enjoyed lay and clerical, popular and institutional, belief in their sainthood; those who did not, did not. This cornerstone could support a number of different constructions of Christian sainthood, but not an infinite number: hence its usefulness to those studying the social and cultural significance of medieval religious expressions, and hence also one significance of Laurence of Oxford's cult. Analysis of the movement suggests that it deviated from the medieval church's concept of sanctity, something that was common throughout the Middle Ages. In addition, though, it deviated from the categories of saints' cults that scholars have found useful in their own conceptualization of medieval holiness: it reveals clerical participation in, and perhaps even direction of, a type of religious movement that scholarship has previously considered evidence of a continued division between lay and clerical culture. It is highly unlikely that the cult's variation from previously studied movements represents a unique or unknown form of

\footnotetext{
${ }^{54}$ Dalderby gave the abbot permission to depart the monastery on pilgrimage in a letter dated 26 May 1313. Two royal records, the first dated 10 May and the second 23 May, gave him leave to depart the kingdom and travel overseas for up to a year. LAO, Episcopal Register 3, fol. 274v; CPR, Edward II, 572, 589 .

${ }^{55}$ For discussion of medieval sainthood, see Renate Blumenfeld-Kosinski and Timea Szell, eds., Images of Sainthood in Medieval Europe (Ithaca, NY, 1991); Peter Brown, The Cult of the Saints: Its Rise and Function in Latin Christianity (Chicago, 1981); Richard Kieckhefer, Unquiet Souls: Fourteenth-Century Saints and Their Religious Milieu (Chicago, 1987); Aviad M. Kleinberg, Prophets in Their Own Country: Living Saints and the Making of Sainthood in the Later Middle Ages (Chicago, 1992); André Vauchez, Sainthood in the Later Middle Ages, trans. Jean Birrell (Cambridge, 1997); and Donald Weinstein and Rudolph M. Bell, Saints and Society: The Two Worlds of Western Christendom, 1000-1700 (Chicago, 1982).

${ }^{56}$ See n. 3 above for summary of this historiography.
} 
sanctity. Rather, the evidence hints at a social dynamic not revealed by other sources, one in which links between parishioners and local clergy overcame clerics' obligations to promulgate the forms of piety prescribed by the institutional church and instead encouraged them to participate with their lay neighbors in a form of saint's cult long since rejected by their ecclesiastical superiors.

Sainthood began in the earliest Christian times with popular acclamation of those who had won the crown of martyrdom through suffering and dying for their faith, but by the fourteenth century the institutional church had gained the exclusive power to determine who received the honor of canonization. ${ }^{57}$ Though the church also claimed the power to determine the qualities of holiness, popular recognition remained at the core of potential saints' cults. Lay recognition of sainthood was never completely shaped by learned, clerical constructs of holiness, and thus no single form of sainthood ever presented itself.

André Vauchez, in his highly influential typology of late medieval saints, has argued that saints' cults may be grouped into three categories defined both by the characteristics of the individuals so honored and by those groups who supported and opposed them. The first two groups, "official" and "local" sainthood, both conformed broadly to clerical models of sanctity. As the name would imply, official sainthood was characterized by the formal efforts of members of the ecclesiastical hierarchy (usually including a bishop) to promote the case for an individual's canonization. The petition for canonization, which required written documentation of the person's living holiness and of his or her posthumous intercession between God and humankind, had to go through the papal curia and ultimately ended before the throne of St. Peter. The narrow path to canonization admitted a fairly limited group of people into the ranks of the saints: although different parts of Europe tended to produce different types of saints, official saints of the later Middle Ages were usually individuals of aristocratic birth, men very high in the ecclesiastical hierarchy (cardinals and popes rather than bishops), or associates of the Mendicant movements, though members of the laity gained ground in the fourteenth century. ${ }^{58}$

Local saints could have many similarities to official saints, but they did not achieve sufficiently widespread acclamation or institutional support to proceed beyond community identification as holy or blessed. As with official saints, they took a variety of forms: in northern Europe, for example, a "suffering leader" such as a bishop who had endured opposition or persecution was likely to be honored by a local cult, while the Mediterranean world put less stock in aristocratic birth or high position and was instead partial to Mendicants or other practitioners of religious asceticism. ${ }^{59}$ Local saints often emerged because a community sought a patron or protector, and though Vauchez's discussion is largely limited to new saints, other local movements, such as villages newly dedicating themselves to an established saint, may probably be placed in this category. ${ }^{60}$ The protective function of saints and the prestige that

\footnotetext{
${ }^{57}$ For development of the canonization process see Vauchez, Sainthood, chaps. 3-6; also Pierre DeLooz, "Towards a Sociological Study of Canonized Sainthood in the Catholic Church," in Saints and Their Cults: Studies in Religious Sociology, Folklore, and History, ed. Stephen Wilson (Cambridge, 1983), 189-216.

${ }^{58}$ Vauchez, Sainthood, 263-79, 283.

${ }^{59}$ Ibid., 158-73, 183-212.

${ }^{60}$ William A. Christian Jr., Local Religion in Sixteenth-Century Spain (Princeton, NJ, 1981).
} 
a saint's presence could give often made local saints a unifying force: the need for protection is shared by all humans alike, and in the creation of new saints, the interests of members of the clergy and of the laity could often coincide. ${ }^{61}$ Without support in larger clerical circles, local saints could not proceed along the road to canonization, but they could still persist undisturbed because ecclesiastical authorities considered them harmless, if not to be encouraged. ${ }^{62}$

Official and local saints represent the pervasiveness of clerical models of sanctity in the medieval world, though not the wholesale imposition of those models on the laity. For example, while laypeople did not necessarily share the institutional church's preference for the celibate clergy when creating new saints, they were entirely familiar with the spiritual force carried by asceticism, and lay holy people and aspiring saints practiced self-denial to various degrees both for their own spiritual benefit and to demonstrate their holiness to others. ${ }^{63}$ Lay supporters of potential saints recognized as well the value of written hagiographical accounts and miracle collections in establishing someone's holiness and encouraged their production. ${ }^{64}$ Even as laypeople created and popularized their own representatives of sanctity, then, the better-documented examples of lay-supported, new saints' cults typically revealed adaptation of contemporary clerical models of sainthood.

Cults in Vauchez's remaining category of the "popular" saint were less likely to conform to the models of the institutional church. ${ }^{65}$ The subjects of these cults, typically even smaller than local movements, might demonstrate the virtues that the institutional church expected in holy people, but virtue was not their salient characteristic. Rather, the defining commonality that led Vauchez to place individuals in this group was that all within it died in "peculiarly horrible circumstances." ${ }^{66}$ Saints in this last group were often found in England: while everyone liked a good martyr, England had a particular penchant for sanctifying victims. Some of these individuals were "political" saints such as Simon de Montfort or Thomas of Lancaster, who won fame and followers by dying in a struggle against royal authority. ${ }^{67}$ Another subgroup within this category was young boys who were the purported victims of Jewish ritual murder. ${ }^{68}$ The least documented but probably most common type of popular saint, however, was the humble and virtually unknown lay victim of injustice. ${ }^{69}$

Popular saints could, in some circumstances, win widespread renown. In En-

${ }^{61}$ Ibid., 147-50; Vauchez, Sainthood, chap. 10.

${ }^{62}$ Vauchez, Sainthood, 85-103; Christian, Local Religion, 161-62.

${ }^{63}$ Kieckhefer, Unquiet Souls, 118-21, 139-49. Over the course of the later Middle Ages, the institutional church too extended the honor of sainthood more and more frequently to laymen and laywomen. Vauchez, Sainthood, 263-67.

${ }^{64}$ Kleinberg, Prophets in Their Own Country, 40-70.

${ }^{65}$ Vauchez, Sainthood, 147-56.

${ }^{66}$ Ibid., 147.

${ }^{67}$ Ibid., 155-56; see also Jennifer R. Bray, "Concepts of Sainthood in Fourteenth-Century England," Bulletin of the John Rylands University Library 66 (1984): 40-77; Claire Valente, "Simon de Montfort, Earl of Leicester, and the Utility of Sanctity in Thirteenth-Century England," Journal of Medieval History 21 (1995): 27-49; and Simon Walker, "Political Saints in Later Medieval England," in The MacFarlane Legacy: Studies in Late Medieval Politics and Society, ed. R. H. Britnell and A. J. Pollard (New York, 1995), 77-106.

${ }^{68}$ Vauchez, Sainthood, 154-55.

${ }^{69}$ Ibid., 147-54. 
gland, for example, political saints could persist as long as there were supporters of their cause, a fact that caused some subsequent monarchs to seek the "neutralization" of political saints' potential effects by themselves supporting the cults. ${ }^{70}$ Accusations of Jewish ritual murder became more and more widespread over the course of the high Middle Ages, with an attendant rise of veneration of its supposed victims. ${ }^{71}$ Both these types of cults might begin at the instigation of clerical proponents, and both movements might be recorded through hagiographical materials and miracle collections designed to demonstrate the individuals' sanctity. None, however, ultimately attained canonization. ${ }^{72}$

Popular veneration of humbler and lesser-known saints received even less clerical support. Venerations of these individuals were ephemeral and poorly documented, surviving almost exclusively in scattered, disapproving references remaining in chronicles or collections of exempla. ${ }^{73}$ The subjects of these cults often differed demographically from the other subgroups in the popular model: unlike alleged victims of Jews, they included adults of both sexes, and unlike political saints, they were not of aristocratic birth. ${ }^{74}$ Particularly notable about these popular saints was the absence of clerical defense of their cults. Rather than unifying laity and local clergy, as local saints could do, Vauchez concluded that these popular movements were always lay in origin and persisted in spite of clerical opposition. When the local clergy did support devotions to a popular saint, he suggested, they did so out of toleration for lay belief or in an effort to draw the movement under the church's wing. ${ }^{75}$ Rather than lay adoption of contemporary clerical models of sanctity, then, Vauchez argued that most saints in the popular model represented a near-autonomous, lay continuation of an ancient type of Christianity that endured long after the institutional church had transformed sanctity, once conferred automatically on men and women who died heroic Christian deaths, into a quality earned by a heroically Christian life.

Most of the characteristics of the Peterborough cult would place it in the last subgroup of Vauchez's popular category. Laurence of Oxford was of lay status and presumably humble birth. There is no indication that he was considered a particularly virtuous person in life, given the apparent popularity, if not necessarily the veracity, of the rumors of sodomy with Godfrey of Crowland. His trial and execution, however, could easily have raised the specter of injustice. Godfrey's position as both the alleged victim of Laurence's crime and the authority responsible for carrying out his execution could, in and of itself, cast doubt on the fairness of Laurence's death. Furthermore, Godfrey stood previously accused of sexual misconduct with both Laurence's wife and Laurence himself, and Laurence's position as the abbot's servant placed him in an inherently close and subordinate relationship to Godfrey. Regardless of whether Laurence's conviction and punish-

\footnotetext{
${ }^{70}$ Walker, "Political Saints," 86.

${ }^{71}$ John M. McCulloh, "Jewish Ritual Murder: William of Norwich, Thomas of Monmouth, and the Early Dissemination of the Myth," Speculum 72 (July 1997): 698-740; R. I. Moore, The Formation of a Persecuting Society: Power and Deviance in Western Europe, 950-1250 (Oxford, 1987), 36-38; Vauchez, Sainthood, 154-56.

${ }^{72}$ Vauchez, Sainthood, 414.

${ }^{73}$ Ibid., 143.

${ }^{74}$ Ibid., 148-51

${ }^{75}$ Ibid., 142, 153
} 
ment were just, it would not have been difficult for someone so inclined to argue otherwise.

In an ironic juxtaposition, Laurence's remains were interred only yards away from Peterborough Abbey's relics of St. Thomas Becket. In almost every way, his cult was the inversion of Becket's. The murdered archbishop's episcopal prestige and gory murder at the instigation of the royal authority he had resisted gave him a near-universal appeal. ${ }^{76}$ Laurence of Oxford, a legally executed felon, held no notable position, and his death was of no interest to anyone beyond Peterborough's environs. His cult, however, tapped into the same deep well that Becket's did: ancient Christian beliefs in the power of martyrdom. The institutional church ardently supported Becket's cult because he was precisely the sort of martyr they wished to promote, but the appearance of new, popular martyrs throughout the course of the Middle Ages shows that church authorities could harness but never fully control that power.

In spite of the commonalities between Laurence's cult and those of Vauchez's popular saints, it was not merely a remnant of archaic beliefs lurking among the laity. Ecclesiastical authorities opposed venerations at Laurence's burial place, as was typical in popular movements. It seems that the local clergy, however, did not merely accept the cult passively or offer their lukewarm support as an endeavor to domesticate lay adherence to an outdated and potentially unruly piety. Rather, John Dalderby believed that the local clergy purposefully promoted this movement in what was the most dramatic, and perhaps final, act in a continuing protest against the abbot of Peterborough.

\section{THE PERPETRATORS}

Who, then, were the disgruntled clerical narrators of the story told only indirectly in Dalderby's letters? Based upon what he had seen in his own visitation of the monastery and in the reports subsequently relayed to him, the bishop believed that they were both brothers in the house and priests in the surrounding parishes. They were, in other words, men whose proximity to the abbot may have lent verisimilitude to any stories they relayed about him, and men whose clerical status would have lent weight to their advocacy of the cult.

Several of Dalderby's letters addressed the culpability of Peterborough's monks both by name and by implication. The most useful is his third on the subject, issued 8 August $1313 .^{77}$ The bishop began with a summary of his visitation of Peterborough in May of that year: the occasion of Godfrey's second purgation. During that visit, Dalderby recounted, he had discovered "dissensions and schisms" within the monastery; in response, he had forbidden "conspiracies and confederations" that would disturb the peace and quiet of the house and its residents. The bishop had lately heard, however, that two monks named William of Walton and Geoffrey of Wardington were behaving as enemies of that monastic tranquility. In addition, they continued to encourage the multitude to worship at Laurence's burial place in spite of and contrary to the bishop's injunctions against the practice. Indeed, the monks had supposedly preached that the bishop and his clerics were

\footnotetext{
${ }^{76}$ Ibid., 167-73.

${ }^{77}$ LAO, Episcopal Register 3, fol. 280v.
} 
ignorant and uninformed about Godfrey's deceitful administration and had thus unjustly forbidden access to the site; according to the bishop's informants they were now publicly preaching a great many things to the detriment of both the bishop's stature and that of the abbot. ${ }^{78}$ Nor were William and Geoffrey the only culprits: in a letter dated 21 August, Dalderby stated that many others also had been found guilty of disturbing the peace of the monastery and encouraging the multitude to gather at Laurence's grave. ${ }^{79}$

Though the cult expressed ongoing struggles between the brothers of Peterborough and their abbot, those struggles could not have been exclusively internal. Monks were not as cloistered as the Benedictine Rule prescribed but had few opportunities to preach to individuals who had not entered the abbey's precincts to visit its shrines or for some other reason. The cult must have had promoters beyond the monastery walls, and in fact Dalderby believed that members of the secular clergy had both tacitly and openly encouraged people to follow the movement. His first letter pertaining to the cult, for example, had instructed the rural deans of Peterborough, Stamford, and Ness to forbid people to gather at the grave site to worship there.$^{80}$ Rural deans were minor ecclesiastical officials charged with dealing with disciplinary matters pertaining to the laity, but Dalderby's next missive complained that the deans of Ness and Peterborough had been lax in carrying out his orders. ${ }^{81}$ This letter ordered that both delinquent deans and a priest named Stephen Cobbe be summoned to appear before the bishop in six weeks' time to answer charges about their idleness in moving against the forbidden practices. Other secular clergy allegedly supported these practices more actively; Dalderby's final letter pertaining to the cult prescribed penance for Stephen Cobbe and two other priests, Hugh of Thurlby, and Richard, vicar of the parish church in the town of Peterborough, for encouraging the people to follow the cult. ${ }^{82}$

The motivations of those particular men cannot now be recovered, but several of them may have been associated with specific points of friction between Godfrey and his ecclesiastical subordinates. According to Henry Pytchley, the Peterborough monk who wrote on the abbey's properties in the last years of the fourteenth century, Godfrey's management of abbey lands in Walton had been a source of tension between him and his monks. It may be no coincidence that a man from that area, William of Walton, was sowing dissension within the house a few years later. ${ }^{83}$ Hugh of Thurlby probably served as a chaplain at the priory of nuns of

\footnotetext{
${ }^{78}$ Ibid., "nos et clericos nostros tanquam inscios et ignaros ad subdolam procuracionem abbatis dicti monasterii accessum populi ad locum predictum contra deum et iusticiam perperam inhibuisse, et quamplurima alia enormia in status nostri et dicti abbatis derogacionem non modicum publice predicarent."

${ }^{79}$ LAO, Episcopal Register 3, fol. 281v.

${ }^{80}$ LAO, Episcopal Register 3, fol. 276v.

${ }^{81}$ William J. Dohar, The Black Death and Pastoral Leadership (Philadelphia, 1995), 19-20; LAO, Episcopal Register 3, fol. 279, 6 August 1313.

${ }^{82}$ LAO, Episcopal Register 3, fol. 289v, 4 November 1313.

${ }^{83}$ It should be noted that place-names could become family names, and so a locative is not a positive indicator of an individual's place of origin. Barbara Harvey, Living and Dying in England, 1100-1540: The Monastic Experience (Oxford, 1993), 75.
} 
St. Michael's in Stamford. ${ }^{84}$ St. Michael's had been founded by Peterborough and was under its guardianship, but the relationship between the two houses was rocky; tensions between them may have inspired Hugh's involvement in the movement. ${ }^{85}$ The vicar of Peterborough's parish church, Richard of Wansford, may have had a strained relationship with the abbot by the very nature of his office; although Peterborough's parish church, St. John the Baptist, paid a higher stipend than most vicarages, the underpayment of vicars was a common complaint in medieval sources, and the vicar's obligation to collect some of the revenues his parish owed its patron could not have made his lot any easier in the worsening economic times of the early fourteenth century. ${ }^{86}$

This active role of the clergy in the Peterborough movement marks the greatest distinction between it and other popular, unsanctioned religious movements. Vauchez's research suggested that similar cults were lay in origin; he concluded that clerical support of them was a "salvage operation" intended to bring under the church's wing movements that actually indicate "a large autonomy in popular representations of sanctity." ${ }^{" 87}$ In his study of the most famous popular cult- that of the spurious St. Guinefort-Schmitt concluded that the movement represented division and friction between lay and clerical culture. ${ }^{88}$ This was not the case with the Peterborough cult, for whether or not those members of the clergy originated the movement, they purposefully perpetuated a cult that flew in the face of the clerical model of sanctity.

\section{THE AUDIENCE}

No matter what tensions strained the clerical spheres in which Godfrey, the monks, and the parish clergy moved, the cult could not have flourished if it had not found a receptive audience and advocates among the laity. Monks and parish priests, like the majority of other people in the Middle Ages, lived out their lives near their birthplaces, and so the clerics identified as promoters of the cult were probably local men who had friends and family among their listeners. Neither kinship nor friendship alone, however, is likely to account for some of Laurence's followers' persistence. Those who continued to worship at the grave site in spite of the bishop's injunctions to the contrary faced excommunication, and yet they did so anyway, gathering secretly and by night. ${ }^{89}$ Dalderby, unfortunately, had no interest in identifying who those obstinate men and women were or why they followed the cult. Even so, his letters hint at the answers to both of those questions.

The supporters of Laurence's cult came from the area immediately around the

\footnotetext{
${ }^{84}$ The register of Dalderby's predecessor, Oliver Sutton, shows that a priest named Hugh of Thurlby held his (unspecified) position from St. Michael's Priory, Stamford, upon his ordination in 1296. Hill, ed., Rolls and Register, 7:69, 79, 86.

${ }^{85}$ VCH Northants., 2:98; Raban, White Book, xxiii, xxx.

${ }^{86}$ Richard of Wansford, a subdeacon at the time he was presented to the vicarage, was ordained a deacon and instituted to the church on 17 March 1291. He was made a priest a month later, on 12 June. Hill, ed., Rolls and Register, 7:9, 12, 17. For discussion of vicars' economic positions, see Pounds, History of the English Parish, 53-54, 202-3; and Hartridge, History of Vicarages, 41 and chap. 7.

${ }^{87}$ Vauchez, Sainthood, 152.

${ }^{88}$ Jean-Claude Schmitt, The Holy Greyhound: Guinefort, Healer of Children since the Thirteenth Century, trans. Martin Thom (Cambridge, 1983), 169-70, 177-78.

${ }^{89}$ noctanter et latenter. LAO, Episcopal Register 3, fol. 279.
} 
abbey and its dependent town. This can be deduced from the recipients of Dalderby's first letters: the rural deans of Peterborough, Stamford, and Ness, who had authority only over parishes within or near the Soke of Peterborough. ${ }^{90}$ That the bishop never ordered his admonitions publicized more widely suggests that the cult was very local in scope, but geography alone does not account for the movement's appeal, since parishes in the neighboring counties of Cambridge and Huntingdon were apparently unaffected. Why did the cult find a following in Stamford, ten miles distant, but not reach an audience in Huntingdonshire, less than a mile away and easily reached by a bridge Godfrey himself had built? ${ }^{91}$ The most likely answer is that the former fell under the abbot's secular control, and the latter did not. ${ }^{92}$

This article intends in no way to dismiss genuine spiritual motivations for medieval religious movements, as historians too often have done. No matter what pious impetus may have contributed to this particular cult, however, the evidence implies that the people who followed it believed they suffered under Godfrey's stewardship. The most telling indication of this motivation is Dalderby's letter of 8 August, listing the supposed misdeeds of the rogue monks William of Walton and Geoffrey of Wardington..$^{93}$ These men, the bishop complained, had preached that his orders to forbid access to Laurence's grave site were unjust. They did not attribute the injustice to any malice or fault on Dalderby's part-the bishop was known as a pious man and a conscientious shepherd of his flock-but rather, to his ignorance about Godfrey's bad leadership. ${ }^{94}$ As the head of both a wealthy monastery and the authority in the Soke, Godfrey was landlord to a great many people in Peterborough's vicinity and beyond. He was the man to whom renters ultimately paid their rents, serfs rendered their manorial obligations, and the town delivered its fines and dues. In following Laurence's cult, those tenants, serfs, and townspeople showed that they found the abbot's management so distasteful that they accepted the monks' and clergy's implications that God himself, by working miracles through Laurence's relics, had passed judgment against Godfrey's governance.

\section{RESOLUTIONS}

No clear indicator of resolution of the broader troubles in the monastery and beyond survives in the extant sources, and remnants of discord within the abbey seem to have lingered for some time. In October 1313, the bishop issued another certification that Godfrey had been found innocent of the things rumored about him the previous May; this second declaration was necessary because the allegations had lately been revived out of "hatred and malice." 95 The following May, Dalderby

\footnotetext{
${ }^{90}$ LAO, Episcopal Register 3, fol. 276v.

${ }^{91}$ Sparke, Historiae Anglicanae, 2:163.

${ }^{92}$ The Soke of Peterborough included the southern suburb of the town of Stamford, Stamford Baron, which fell in the deanery of Stamford. The deanery of Ness bordered that of Stamford and the abbot possessed a manor (Thurlby, from which Hugh of Thurlby presumably came) within it. For Stamford, see VCH Northants., 2:522.

${ }^{93}$ LAO, Episcopal Register 3, fol. 280v.

${ }^{94}$ For a brief summary of Dalderby's career see William Page, ed., The Victoria County History of Lincoln (London, 1906), 2:34-36.

${ }^{95}$ LAO, Episcopal Register 3, fol. 285.
} 
again gave Godfrey license to depart on pilgrimage for the remission of his sins and the lifting of his sorrows by a "change in the air"-air that was, perhaps, less palpably charged with the resentment of his disgruntled brothers. ${ }^{96}$ The last echo of strife is a final letter from Dalderby, dated 19 March 1316, enjoining his representative to visit the monastery and reconcile monks who still remained excommunicate for their part in the cult. ${ }^{97}$ Tensions within the abbey, however, no longer manifested themselves in popular venerations at Laurence's burial place. Perhaps the laity somehow became more satisfied with Godfrey's leadership, but a much more likely reason for the collapse of the cult is that by the end of 1313 , the bishop had apparently succeeded in dissuading the parish clergy from preaching it.

The capitulation of the parish clergy is indicated by a letter, written 4 November 1313, that prescribed the penance of three priests (Stephen Cobbe, Hugh of Thurlby, and Richard the vicar of Peterborough's parish church) and one layman (John Cook) who had promoted the cult. ${ }^{98}$ The period of penance for all four men began after the Feast of the Epiphany, 6 January. For three successive Sundays each of the priests was to stand in the middle of the town's parish church during mass, when a very large crowd of people was present. ${ }^{99}$ They were to wear their clerical surplices, but their heads and necks would be bared, and each was to hold a crucifix above his head while publicly proclaiming his errors. John Cook, the layman, had to perform his penance outdoors. On three successive market days he was to stand in the marketplace with his head, neck, arms, and legs bare and divested of his tunic and belt-a chilly prospect in January in the fenlands. Like the priests, John was to carry a crucifix in one hand, but in the other he was to hold a switch. Then the parish clergy of the regions around Peterboroughspecifically, those clerics who were not guilty of the heresy he had perpetuatedwere to whip him with his switch while explaining to the onlookers the reason for John's beating. ${ }^{100}$ Furthermore, for the next seven years all four men had to make a yearly pilgrimage on foot to the cathedral church of Lincoln (about fifty miles north of Peterborough) and make offerings there.

Private confession and penance were commonly practiced by the fourteenth century, but public penance was still performed to expiate "public" sins, including sins against the church; the public demonstration of the individual's acceptance of his or her own error served to invalidate that which he or she had previously advocated. ${ }^{101}$ Making an example of these three priests must have been crucial to ending the movement, for while local clergy may have had more in common with their lay fellows than with bishops or abbots, their status as members of the clergy

\footnotetext{
96 "pro remedio peccatorum et vestre egritudinis relevamine aliquali, quod in inmutacione aeris posse creditur vos sentire." LAO, Episcopal Register 3, fol. 297v.

${ }^{97}$ LAO, Episcopal Register 3, fols. 343-343v.

${ }^{98}$ LAO, Episcopal Register 3, fol. 289v.

${ }^{99}$ Ibid., "cum maior assuerit populi multitudo ibidem."

100 "Heresy" in the Middle Ages meant not only doctrinal error but also persisting in error after correction, which was John's sin. Malcolm Lambert, Medieval Heresy: Popular Movements from Bogomil to Hus (New York, 1976), 4.

${ }^{101}$ Mary C. Mansfield, The Humiliation of Sinners: Public Penance in Thirteenth-Century France (Ithaca, NY, 1995), 41-49. See Scott, Domination, 56-58, for similar uses of public apologies in other social and political contexts.
} 
would still have given the cult a legitimacy that lay worshippers could not. As long as they advocated or condoned Laurence's cult they defied the bishop's authority as well as Godfrey's; as long as they advocated or condoned Laurence's cult, they themselves perpetuated division not only within the body of the church - the body of Christian believers-in the religious communities around Peterborough, but also within the order of the clergy. The priests' proclamation of their error no doubt was intended, not merely to invalidate what they had previously taught about the cult, but also to show publicly their recognition of the authority of the bishop himself, who had condemned the movement. Their yearly pilgrimages to the cathedral of Lincoln would have served as a private reminder of the same thing. Their penance, if carried out, restored the right order of things. With their surrender the cult faded into obscurity, and the written echoes of its followers' voices vanished from the historical record.

\section{CONCLUSIONS}

At the time Laurence's cult appeared, Godfrey had been abbot for well over a decade. The evidence does not tell why things came to a head in 1313 , but by then England had entered a period of population and climatic stress that would culminate in the Great Famine of 1315-17. ${ }^{102}$ The abbey's tenants may have been struggling to pay what they owed their landlord, and their resentment against him perhaps grew accordingly. ${ }^{103}$ The parish priests who served as vicars in the abbey's appropriated churches and were responsible for collecting some of the tithes owed to it would have felt the pinch as well. Unlike the laity and parish priests, the monks owed no income to the house; rather, it supported them. They had, however, little control over the disposition of the abbey's goods or income. That power rested with the abbot and other monastic officers, and the monks may have had just reason to criticize the abbot's management. Large monasteries throughout England were struggling financially in the early fourteenth century; under the circumstances, Godfrey's monks may have felt his refurbishments of his residence at Eye and other projects in the previous few years were not the best use of the house's resources. ${ }^{104}$

It should be noted that complaints about abbatial mismanagement were common throughout England in this period. ${ }^{105}$ The rumors against Godfrey, however, included alleged personal immorality in addition to administrative failings. Practical reasons may have shaped those accusations - it was far more serious for an abbot to carry on various and sundry romantic affairs with persons of both sexes than to mismanage the resources over which the Rule gave him authority. Nonetheless, the persistence and breadth of Laurence's cult suggests that it represents only one

\footnotetext{
${ }^{102}$ See William Chester Jordan, The Great Famine: Northern Europe in the Early Fourteenth Century (Princeton, NJ, 1996).

${ }^{103}$ Ibid., 51.

${ }^{104}$ See Still, Abbot and the Rule, 79-80, and Gorsuch, "Mismanagement," for discussion of monasteries' economic problems in the early fourteenth century. According to Whittlesey, Godfrey spent nearly $£ 125$ on his building projects in the twelfth year of his abbacy (October 1310-11), £84 of which went to improvements of the manor at Eye. Sparke, Historiae Anglicanae, 2:164.

${ }^{105}$ Gorsuch, "Mismanagement."
} 
facet of a broader dissatisfaction with Godfrey in both the religious and lay communities, not a simple protest against his new pantry and buttery. ${ }^{106}$

Common lay and clerical advocacy of the Peterborough cult quite clearly supports the scholarship emphasizing the significance of shared religion, culture, and social ties between members of the laity and of the clergy. In fact, it shows this commonality intruding into a phenomenon that has previously been identified as characteristically lay: the creation of saints identified as popular in Vauchez's typology. This apparently uncommon collaboration, I would argue, reflects not any unusual social or religious dynamics, but rather, was made possible by a quite normal cultural context. The parish clergy were supposed to be "intermediaries" between the institutional church and the laity, figures charged with bringing correct belief and practice to their flocks. At the same time, however, they were products of the social groups to whom they ministered, and it is wholly natural that they would have shared their beliefs about sanctity and religious expression. ${ }^{107}$ The movement as revealed in Dalderby's letters is almost certainly a previously unseen manifestation of that shared religious and social culture: what is atypical about it is the unusual circumstances that made it possible, and the unusual set of disciplinary sources preserved through the English bishops' practice of keeping diocesan registers and Dalderby's own diligence in performing his pastoral duties. ${ }^{108}$

Laurence's cult indeed represents a social divide, but the fracture did not fall between the clergy and laity, or even between the monastery and parish, as could happen. ${ }^{109}$ Rather, the break divided those with institutional authority from those without it. Godfrey's authority over the monastery came from the Benedictine Rule, which said that he was the representative of Christ in the house, and his jurisdiction over the town of Peterborough came from royal charters, which identified him as the legal authority over the Soke. The proponents of Laurence's cult were not completely without power or influence: rural deans and parish priests had a certain authority, and the residents of the Soke of Peterborough, particularly free ones, had legal rights. Nonetheless, their institutional means to influence the abbot's behavior, though extant, were limited.

Monasteries could try to procure their abbot's deposition or resignation by convincing the appropriate bishop of his unfitness, as the monks of Peterborough had succeeded in doing in 1249 , but this was a difficult prospect. ${ }^{110}$ Towns in conflict with a governing monastic house could seek legal redress in secular or ecclesiastical courts, though there was no guarantee that those efforts would meet with long-term success, as the citizens of St. Albans discovered when they successfully sued in 1327 to use their own mills rather than that of St. Alban's abbot, only to have the king take that right away a few years later. ${ }^{111}$ When struggles between towns and monasteries involved the interests of multiple authorities (such

\footnotetext{
${ }^{106}$ Sparke, Historiae Anglicanae, 2:164.

${ }^{107}$ Aron Gurevich, Medieval Popular Culture: Problems of Belief and Perception, trans. János M. Bak and Paul A. Hollingsworth (Cambridge, 1988), 11; Pounds, History of the English Parish, 155-56.

${ }^{108}$ For episcopal registers see M. T. Clanchy, From Memory to Written Record (Oxford, 1993), 74-76.

${ }^{109}$ Andrew Brown, Popular Piety in Late Medieval England: The Diocese of Salisbury, 1250-1550 (Oxford, 1995), 36-38; French, "Competing for Space"; Still, Abbot and the Rule, 109-14.

${ }^{110}$ Matthaei Parisiensis Chronica Majora, ed. H. R. Laud, Rerum britannicarum medii aevi scriptores 57 (1880), 5:84-85.

${ }^{111}$ Still, Abbot and the Rule, 112-14.
} 
as a monastic house and a lay patron), or could be drawn into either secular or ecclesiastical courts, both sides could manipulate those legal processes for their own ends. ${ }^{12}$ No evidence of similar efforts appears in the Peterborough case, perhaps because whatever instigated the troubles did not overstep the bounds of Godfrey's secular powers, and ecclesiastical authority had twice supported Godfrey when the bishop accepted his oaths of innocence at his compurgations. Laurence of Oxford's execution, however, provided a felicitous-for Godfrey's opponentsopportunity to invoke a much higher authority.

People treated Laurence's grave site as a holy place because miracles had supposedly occurred there. ${ }^{113}$ By definition, a miracle was an act of the divine, and it was a signifier distinguishing saints and martyrs from other people. ${ }^{114}$ The attribution of the signs of martyrdom to Laurence could only have been intended to show divine disapproval of his death and, therefore, divine disapproval of the man who had caused it. Though Dalderby, of course, chose not to make explicit the connection between the cult and resentment against Godfrey, his letters strongly suggest that the advocates of Laurence's cult connected it to the larger spectrum of Godfrey's supposed misdeeds, not merely to the circumstances of Laurence's execution. In October 1313, for example, the bishop reissued his certification of Godfrey's innocence in the allegations made about him the previous May; they were, then, still circulating as the cult continued. ${ }^{115}$ In addition, one phrase in the bishop's letters implies an open association between Laurence's purported holiness and the abbot's sullied reputation. On 6 August, Dalderby complained that he had heard of a "scandalous song" (carmen famosum) being sung at the grave site. Followers of a new cult might develop a hymn in the potential saint's honor; if the carmen was simply a hymn, it is unsurprising that Dalderby would consider it offensive. ${ }^{116}$ Carmen famosum was also, however, the legal definition of a slanderous song that did injury to someone's reputation. ${ }^{117}$ If such was the case here, the proponents of Laurence's cult explicitly treated the miracles at Laurence's grave site as divine validation of accusations that an earthly ecclesiastical authority had dismissed.

Laurence of Oxford's cult, then, represented a short-lived effort by the monks, parish clergy, and laity of the Soke of Peterborough to discredit the man who had the greatest authority over their lives. They struck against his reputation first through gossip and rumor, and when these methods failed, they continued their efforts through veneration of a martyr of their own making. One final point about the cult, however, remains to be made: why it could emerge in the first place. What about this particular instance made plausible the idea that the grave of this

\footnotetext{
${ }^{112}$ French, "Competing for Space," 223-31.

${ }^{113}$ Unsurprisingly, these miracles went unrecorded, but miraculous cures and healings were the most common type of miracle in the later Middle Ages. Vauchez, Sainthood, 466-68; Benedicta Ward, Miracles and the Medieval Mind: Theory, Record and Event, 1000-1215 (Philadelphia, 1987), 34, 84.

${ }^{114}$ In addition to Ward, Miracles, see Vauchez, Sainthood, 444-53, for discussion of miracles and sanctity.

${ }^{115}$ LAO, Episcopal Register 3, fol. 285.

${ }^{116}$ LAO, Episcopal Register 3, fol. 279; Claire Valente, "Simon de Montfort," 36-37.

${ }^{117}$ Henrici de Bracton de legibus et consuetudinibus Angliae, ed. Sir Travers Twiss (London, 1879), $546-47$.
} 
executed felon could become a place where the divine touched the earth? Ultimately, two reasons present themselves: Laurence and Godfrey.

Laurence's situation, if not unique, must have been highly unusual. Elsewhere too servants stole from their masters, prelates were accused of sexual indiscretions, and people died through the power of dubiously disinterested authorities, but these things must rarely have joined together in one man. This convergence, not the mere prospect of a false conviction, made possible Laurence's treatment as a martyr. It is likely, however, that a different kind of convergence contributed equally to the cult's plausibility: the confluence of two roles in the single person of Godfrey of Crowland.

Godfrey's status as abbot of Peterborough placed him in two somewhat contradictory positions: that of a secular power and that of a spiritual leader. Aspects of this position were common to the heads of most religious houses: the possession of land obliged an abbot to oversee his abbey's tenants and otherwise manage the house's temporalities, though Godfrey seems to have embraced these obligations with more enthusiasm than did some other abbots. Nevertheless, he held more power than most abbots did, as his near-autonomous rights over the Soke of Peterborough made him the only legal authority the residents of the Soke were likely to encounter, and charged him with carrying out duties of justice more commonly done by secular authorities, including executing criminals. He was not, however, a secular lord. Rather, his earthly power came from his spiritual office, and no matter how much the behavior of Benedictine abbots typically deviated from the ideal prescribed by the Rule, he was by definition a religious figure. $\mathrm{He}$ was simultaneously the spiritual father of Peterborough's monks, landlord to its tenants, and the judicial power to whom residents of the Soke answered. The sacred and the earthly worlds intersected in him, and perhaps protest against him could easily and genuinely cross the boundaries between the two. 